\title{
Sustainable development frictions: lifestyle migration on the coast of Jalisco, Mexico
}

\author{
Jennifer Cardinal ${ }^{1}$ \\ Rensselaer Polytechnic Institute, USA
}

\begin{abstract}
The concept of sustainability is materialized differently in luxury ecotourism development and in locallydirected community development initiatives. I examine the diverse environmental ideologies at play in these two distinct incarnations of "sustainable development" on the southern Jalisco, Mexico coast; first, in La Manzanilla, a community inhabited by a proportionately large population of leisure consumption-driven lifestyle migrants, then to the north, in elite ecotourism enclaves and a community displaced by a wealthy developer. I suggest these divergent development incarnations may be understood by expanding the concept of lifestyle migration to include a broader range of enactments of home, from different class perspectives. Global environmental ideologies and lifestyle migrant capital play a fundamental but not the only role in local sustainable development. I suggest global influences and local initiatives are creating a productive friction, reassembling global environmental knowledge and tourism imaginaries to suit local agendas. While there is no consensus on what sustainable development should look like in La Manzanilla, the intersection of initiatives is producing locally-directed development that contrasts with the erasure of local agendas happening in elite costal developments nearby.
\end{abstract}

Keywords: sustainable development, friction, environmental ideology, tourism, lifestyle migration

\section{Résumé}

La durabilité se matérialise de différentes manières dans les initiatives de développement de l'écotourisme de luxe et dans le développement des communautés locales. J'examine les diverses idéologies environnementales en jeu dans ces deux incarnations distinctes du «développement durable» sur la côte sud de Jalisco, au Mexique. Premièrement, à La Manzanilla, une communauté d'écotourisme et de modes de vie d'élite, et deuxièmement, une communauté déplacée par un riche promoteur immobilier. Je suggère que ces chemins de développement divergents peuvent être compris en élargissant le concept de migration de style de vie, vu de différentes perspectives de classe. Les idéologies environnementales mondiales et la capitale des migrants sont importantes dans la nature du développement durable local. Je suggère que les influences mondiales et les initiatives locales créent une friction productive. Ils rassemblent les connaissances environnementales mondiales et les «imaginaires du tourisme» pour les adapter aux agendas locaux. Bien qu'il n'y ait pas de consensus sur ce que devrait être le développement durable à La Manzanilla, l'intersection des initiatives produit une forme de développement dirigé localement qui est très différente de l'absence d'agendas locaux observés dans les développements côtiers d'élite à proximité.

Mots clés: développement durable, friction, idéologie environnementale, tourisme, migration de style de vie

\section{Resumen}

El concepto de sostenibilidad se está materializando de manera disparejo en el ecoturismo de lujo y las iniciativas locales de desarrollo comunitario. Examino las diversas ideologías ambientales en juego en dos

\footnotetext{
${ }^{1}$ Jennifer Cardinal, PhD. Lecturer, Sustainability Studies, Department of Science and Technology Studies, Rensselaer Polytechnic Institute, USA. Email: cardij3 "at" rpi.edu. Acknowledgements: Thanks to the JPE editors and reviewers, reviewers from the Anthropology and Environment Society's Junior Scholar Writing Workshop, and all of my writing group colleagues for thoughtful guidance with the manuscript. This research was supported by funding from the Tinker Foundation and The University of New Mexico Latin American and Iberian Institute, Graduate Professional Student Association, Office of Graduate Studies, and Department of Anthropology. Time and space to write were provided by an Earlham College postdoctoral fellowship. Thanks to the RPI STS Department for a supportive and engaging research and writing community. Thanks to my students for challenging discussions about sustainability and development. Special thanks to research participants and friends in La Manzanilla who generously shared their time and experience.
} 
encarnaciones de "desarrollo sostenible" en la costa sur de Jalisco, México; primero, en La Manzanilla, una comunidad habitada por una población proporcionalmente grande de migrantes por estilo de vida, luego en enclaves de ecoturismo de élite y una comunidad desplazada por una rica compañía desarolladora. Sugiero que estas encarnaciones de desarrollo divergentes se pueden entender usando y ampliando el concepto de migración por estilo de vida para incluir una gama más amplia de representaciones del hogar desde diferentes perspectivas de clase. Las ideologías medioambientales globales y el capital transnacional desempeñan un papel fundamental en el desarrollo sostenible local. Sugiero que las influencias globales y las iniciativas locales están creando una fricción productiva, reuniendo el conocimiento ambiental global y los imaginarios turísticos para satisfacer las agendas locales. Si bien no existe un consenso sobre cómo debería ser el desarrollo sostenible en La Manzanilla, la intersección de iniciativas está produciendo en ese espacio un desarrollo dirigido por actores locales que contrasta significativamente con el desarrollo élite en la costa que elimina las agendas locales.

Palabras clave: desarrollo sostenible, fricción, ideología ambiental, turismo, migración por estilo de vida

\section{Introduction}

How can we make sense of a concept like sustainability, when its meaning takes a multiplicity of shapes in practice? What does sustainability mean to a small community fostering natural resources that are the foundation of their livelihood? What does sustainability mean to a transnational corporation appealing to an environmentally-conscious 'jet set'? What happens to the concept of sustainability when it's paired with development? The UN Sustainable Development goals include promoting inclusive economic growth, creating access to clean water, energy, and quality education, as well as eliminating poverty and inequality. Creating and supporting sustainable communities is a goal with wide appeal on paper, but what does that look like in practice?

This article considers two distinct models of sustainable development on the coast of southern Jalisco, Mexico. On one end of what is known as the Costalegre ("happy coast", Figure 1), beach-front land is being privatized for luxury resort development that claims to prioritize environmental and economic sustainability. On the other end, a locally-directed tourist development process is underway in the small community of La Manzanilla del Mar. These cases illustrate how different environmental ideologies are used in the service of sustainable development, and how dominantly positioned discourses are adapted and challenged in local contexts.

La Manzanilla is a small town with a proportionately large population of foreign resident lifestyle migrants, who are leisure consumption-driven migrants typically from the Global North (Benson and O'Reilly 2009; Benson 2013; Hayes 2015a, 2015b). The category "lifestyle migrant" may be expanded to describe a variety of residents on the southern Jalisco coast, including not only the upper middle-class US and Canadian home owners in La Manzanilla, but also the billionaire jet set home owners in the neighboring luxury destination, Careyes. I suggest a connection between different "sustainable development" incarnations and divergent understandings and enactments of "home" among these lifestyle migrants.

While there is not a consensus on what sustainable development should look like in La Manzanilla, the intersection of global influences and local initiatives is producing locally-directed development that contrasts significantly with the erasure of local control in tourism development in nearby elite eco-enclave costal destinations. I use friction as a conceptual tool to analyze the relationship between lifestyle migrant capital, environmental ideology, and ecotourism imaginaries as they inform locally-directed community development in La Manzanilla, and contrast this development with neighboring elite eco-enclave development.

I conducted 17 months of qualitative ethnographic research between 2009 and 2014, with a focused 13month period in 2012-2013. My position as a researcher was widely known, which helped relieve confusion about how an English speaking woman from the U.S. who was not retired, yet not apparently employed, could afford to live there for a year, but not afford the lifestyle and free spending of the wealthier lifestyle migrants. I collected data from sixty-two research participants in open-ended and semi structured interviews and a questionnaire, daily fieldnotes, digital media, and locally archived documents. Research participants included a purposefully broad spectrum of community members, including diversity in age, gender, employment, and involvement with community and tourism development. Interviews were conducted in English (43) and Spanish 
(19), one on one or in groups, depending on research participant preference, and participants self-identified as Mexican (24), US/American (25), Canadian (8), and European (5 including Dutch, German, Belgian, and British). Names of individuals are pseudonyms. Aside from interviews, I conducted daily participant observation including informal and formal activities focused on understanding lifestyle migrant and local experiences of place, moments of encounter between these groups of residents, and the implementation of development initiatives.

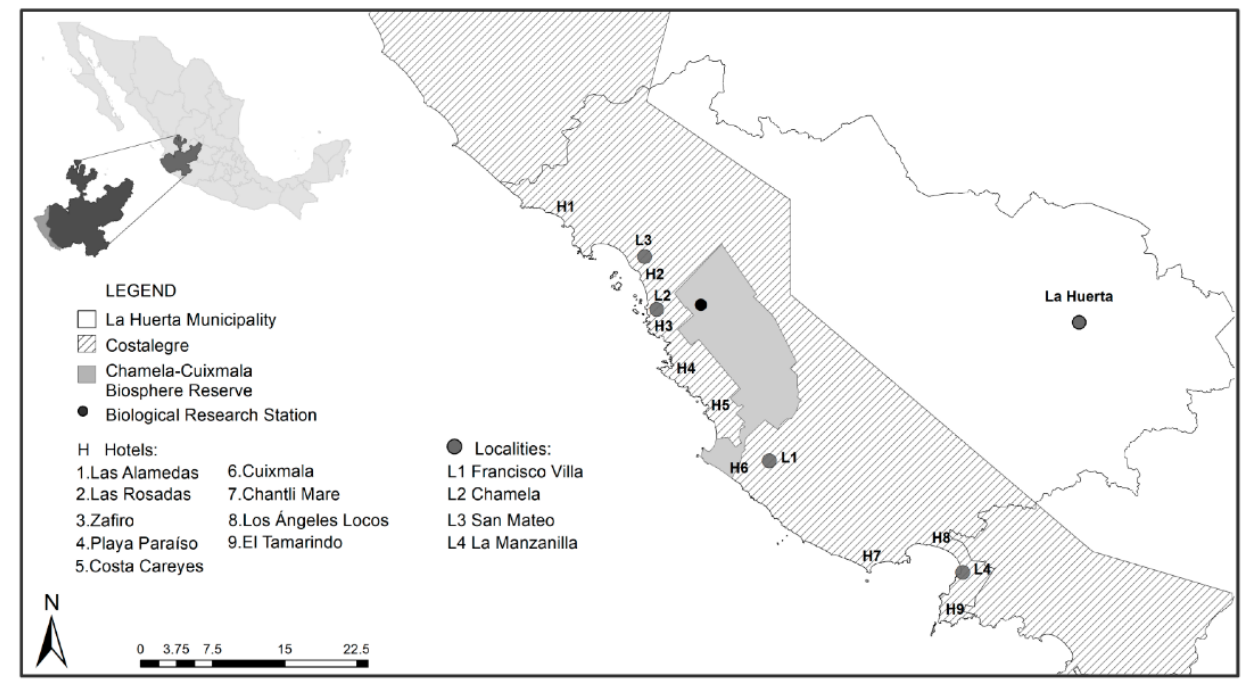

Figure 1: The Costalegre, towns and resorts. Source: Riensche, M. et al. 2019. Copyright: CCBY licence. https://doi.org/10.3390/su11061760

The article proceeds by critically situating sustainable development and suggesting friction as a conceptual tool to elucidate divergent environmental ideologies and practices shaping the Costalegre. Then I introduce La Manzanilla through a brief history highlighting the relationship between lifestyle migration and the town's development. I consider the role of lifestyle migrant capital in the entrepreneurial aspirations of youth, and describe local environmental education and ecotourism initiatives. A discussion of the discordant meanings and practices covered under the prefixes "eco" and "sustainable" helps to transition the article from ethnographic research in La Manzanilla to the neighboring luxury tourism development. I introduce the neighboring sites of elite ecotourism development in Careyes and Chamela through historical reflections and critical discourse analysis of contemporary travel and news media. Finally, I discuss the case of a corporate land take-over and displacement of a community geographically situated between La Manzanilla and Careyes/Chamela. I suggest the unlikely coalition of interests in La Manzanilla represents a protective barrier to this type of development disenfranchisement.

\section{2. "Sustainable" "Development"}

Degrowth and political ecology are both critical of the inherent contradictions in "sustainable" "development." Both challenge dominant knowledge systems, and work to document viable alternatives and create more equitable human-human-environment relations (Paulson 2015, 2017). Degrowth explores sustainability in relation to wellbeing and equity, rather than perpetuating the neoliberal model of progress and development in terms of growth and expansion. Development in La Manzanilla intersects with sustainability along these lines, but within the confines of a reality informed by a neoliberal capitalist global frame. The apparent contradictions in pairing "sustainable" with "development" have been heavily addressed in academic 
works, and continue to play a role in local and global imaginaries (Carrigan 2011; Escobar 1995, 1998; OliverSmith 2010). Development is linked to the ideology of progress, which Oliver-Smith argues, "is intimately woven into the cultural fabric of the West, providing a major ideological justification of colonialism and other forms of economic expansion" (2010: 4). Escobar describes the discourse of sustainable development as development which would, "make possible the eradication of poverty and the protection of the environment in one single feat of Western rationality" (1995: 192). Neoliberal ideology proposes that "human well-being can best be advanced by liberating individual entrepreneurial freedoms and skills within an institutional framework characterized by strong private property rights, free markets, and free trade" (Harvey 2005: 2). I suggest the concept of social sustainability is essential to understand both the contradictions and possibilities of a locallyinformed sustainable development that interacts with and pushes back against neoliberal logics.

Comparable to the emphasis on the value of biodiversity in much of the environmental sustainability discussion, Low (2003) adds a focus on cultural diversity to her definition of social sustainability. Social sustainability in this sense contributes to the often contradictory goals of maintenance and preservation alongside enhancement and revitalization. Local inhabitants of places, in this social sustainability model, must be placed at the center of sustainable development. Social sustainability is thus inextricably entwined with economic and environmental sustainabilities. Factors like quality of life, while not easily measurable, link preservation of social/cultural life with imaginaries of the future and plans for change. Understanding historical and contemporary local meanings and practices are essential to conditions that would support social sustainability. In this context attention to the relationship between sustainability initiatives and inequalities is crucial (Peterson 2015). Conceptions of sustainability and resilience both raise the question of maintaining existing conditions over change, in other words; sustainability for whom? Who has the power "to decide what the 'desired' social-ecological configuration is?" (Nadasdy 2007: 216).

The reality of a subversive sustainable development within the dominant development paradigm is not the picture of a remote community removed from the forces of history. But autonomy and self-determination are essential to social sustainability. Scholars like Escobar have argued for attention to alternative models of social/environmental relations within global capitalism. Social movements offer strong examples of the processes entailed in politically mobilizing these models in practices that work toward both securing autonomy and land for groups marginalized in fields of global economic and political power and protecting biodiversity (Escobar 1998).

While I would not characterize local entrepreneurs and nonprofits in La Manzanilla as a social movement, I do suggest that local sustainability initiatives are both challenging and drawing from dominant development models. The degrowth shift toward "visions of good life variously characterized by health, harmony, pleasure and vitality among humans and ecosystems" is discernable in the diverse practices of La Manzanilla inhabitants (Paulson 2017: 426). These residents may be rather obtusely lumped into artificially delineated groups: locals and foreigners. The foreigners can be further categorized as lifestyle migrants, and the locals can be further specified as those involved in community development, with a focus on the generation that have been raised amid lifestyle migrants for their entire lives.

To analyze the relationship between these residents, and the natural and produced environment, I use the concept of friction (Tsing 2005). This concept "reminds us that heterogeneous and unequal encounters can lead to new arrangements of culture and power" (Tsing 2012: 708). I suggest there is a productive friction in the interactions among "local" and "foreign" residents around sustainable development in La Manzanilla. Environmental justice activists and scholars have found that coalition-building among diverse individuals and groups with interdependent place-based issues can create conditions that are resistant to forces of displacement and disenfranchisement (Banerjee 2017; Bullard 1999; Escobar 1998, 2008). In the case of La Manzanilla, foreign and local residents have created a coalition around a shared investment in their home, if not in an unequivocally unified vision. Tsing points to the reality of friction in collaboration, noting that "parties who work together may or may not be similar and may or may not have common understandings of the problem and the product" (2005: 246-247). Residents of even the smallest communities (often particularly those small communities) do not represent a unified front. There are always competing interests and needs, but they are unified around a shared place. They live there, after all. And that means something. I suggest that friction allows 
a space for understanding local initiatives as contributing to conditions that stave off large-scale threats of disenfranchisement from the outside.

\section{A brief history of La Manzanilla del Mar in the context of tourism development, disaster, and neoliberal reforms}

The community originated after the Mexican Revolution of the early 1900s, when in April 1936 the group of campesinos who lived and worked in the area requested government land and their recognition as a collective farm (known as an ejido) from the government. The town was formally established when the ejido was officially founded in February 1938 during the Cárdenas administration, when 18,352,275 hectares of land were distributed among 1,020,594 citizens across the nation (Krauze 1997: 469).

Tourism development in Mexico is intimately intertwined with the post-revolutionary Mexican national project (Berger and Wood 2010). Tourism was lionized as a panacea that would simultaneously build the economy and solidify a modern national identity. By the 1950s tourism was big business in Mexico, and state and private agents invested in (and to a large extent created) the idea of coastal Mexico as a "tropical paradise" (Clancy 2001). Coastal destinations were imagined and developed to be lucrative features of the tourism economy, and towns like Acapulco and Puerto Vallarta were made accessible to tourists with roads linking them to major cities, ports suitable to host passenger ships, and eventually airports.

In La Manzanilla the economy was based on palm oil harvesting and small scale fishing until the late 1970s and 1980s when a small number of intrepid national and international tourists started arriving, primarily for daily beach use and sometimes camping. A few of these travelers stayed and settled. It was not until the mid-nineties that an influx of largely middle/upper middle class lifestyle migrants from the US and Canada (and some Europeans) came to settle in La Manzanilla. Transnational political and economic transformations, coupled with a devastating tsunami in 1995, led to a transformation in the community.

Many residents in La Manzanilla today correlate the rise in the presence of lifestyle migrants with the tsunami disaster. On October 9, 1995 an 8.0 earthquake hit offshore of the Pacific coasts of Jalisco and Colima causing a tsunami affecting approximately 200 kilometers of coastline (Borrero et al 1997: 85). La Manzanilla was flooded over 2 meters in most areas, submerging the main street and the town square (jardín) as the water did not stop until it hit the steep upward incline 200 meters inland. Local residents describe the tsunami as a turning point in the community, explaining "the tsunami in 1995 marks the beginning of the development in La Manzanilla" (Interview 7/15/13). A lifestyle migrant resident distinguished this time as marking the second wave of settlers; "after the tsunami you have the second wave of gringo development" (Interview 7/30/13). Locals did not want to rebuild on the beach, and the TV coverage of the tsunami made the town visible to international audiences.

Right on the heels of the North American Free Trade Agreement (NAFTA), which opened the door to international corporate investment in Mexico, this local disaster made conditions ripe for what Klein has termed "disaster capitalism" (2005). There are numerous cases of advancing private development agendas in moments of disaster. Honduras, for example, made a post-Hurricane Mitch constitutional reformation to allow foreign land investment on the coast geared toward tourism development. This development agenda displaced locals and was met with resistance (Stonich 2008). It is similar to the amendments to Article 27 in the Mexican Constitution that opened the door to private corporate development of previously state-owned, ejido land (Preston and Dillon 2004). Increased privatization in Mexico during the end of the twentieth century has aggravated socioeconomic inequalities, and this neoliberalization "creates a flat world for multinational corporations and for the billionaire entrepreneur and investor class, but a rough, jagged, and uneven world for everyone else" (Harvey 2009: 58). In La Manzanilla, however, the local impact of these neoliberal agendas paired with the tsunami disaster did not result in state-supported corporate tourism development. It did result in a small wave of lifestyle migrants moving in, building homes on the beach and in the hills, and beginning to participate in community life to various degrees.

Despite the lifestyle migrant and tourist presence, particularly in the winter and during national holidays, La Manzanilla is still understood to be off the beaten path. While the Costalegre has been getting increased 
attention from tourism developers and promoters, La Manzanilla is often left off the map. When it is mentioned, it is frequently as a beach to visit on a day trip from another destination.

Many "snowbird" lifestyle migrants return to the town seasonally, during the frigid winter months in North America. Others have made more permanent transitions to Mexico, and are retired or employed remotely. The lifestyle migrant population (estimated 300) in a town of less than 2,000 people is proportionately large, and has made an impact on the generation of local youth (aged 12-32) that have now grown up in a community never absent from this foreign presence. Lifestyle migrant privilege has been found to reshape the social and material landscapes of communities (Jackiewicz and Govdyak 2015; Janoschka 2009). In La Manzanilla, lifestyle migrant capital and ideology have made an impact on local residents, and there were many examples of local entrepreneurial youths, in their twenties during field research (2009-2014), who were taking a leading role in capitalizing on the lifestyle migrant market and developing tourism in ways that align with their own aspirations, and shaping the town in which they envision their lives unfolding.

\section{Lifestyle migration and community transformations}

Lifestyle migrants in my research echoed some common motivations found in this form of mobility; desiring slower-paced lifestyles, a strong sense of community, and unique natural landscapes south of the border (Banks 2004; Bloom 2006; Clausen 2008; Croucher 2009; Morales 2010; Truly 2006). A lifestyle migrant couple who first visited in 1996 and now own a home conveyed surprise that La Manzanilla is not "overbuilt" and described being drawn to "the lifestyle." They remarked that "it's the community- you're in nature, and yet you have some town, but it's not too much town. It's a lot of beach everywhere. It's kind of an amazing little combination. It's very rare" (Interview 2/28/13).

The undiscovered authentic paradise is a common trope, and can lead to tensions between lifestyle migrants and tourism development. Lifestyle migrants are invested in preserving their adopted communities and have been found to use the tools at their disposal to actively oppose the negative effects of mass tourism development (Janoschka 2009). Common in "residential tourism" is a majority presence of foreigners who view their new homes as a real estate investment rather than a place to live, and research suggests this is not conducive to sustainable development (Barrantes-Reynolds 2011; Jackiewicz and Govdyak 2015; Van Noorloos 2011). In addition to lack of economic benefit to local communities, touristic desires for pristine, secluded landscapes are incompatible with the high-impact development that generally accommodates residential tourism (BarrantesReynolds 2011).

A substantial body of scholarship explores the heterogeneity of lifestyle migrants, highlighting differences in class, motivation, and mobility (Bantman-Masum 2015; Benson and O'Reilly 2009; Cohen et al. 2015; Hayes and Carlson 2018; Spalding 2013). In Lake Chapala, Jalisco, Truly (2006) found a shift in the type of migrants arriving after the enactment of NAFTA, when he suggests "adventurous" migrants were faced with a new group more likely to import aspects of the lifestyles familiar to them. He argues that the shift away from community-involved, adventurous migrants to "importers" is potentially detrimental to the community. The lifestyle migrants I encountered are not easily subdivided into "adventurous adapters" and "importers", but level of community involvement is a distinguishing feature. Corresponding to research in other Latin American destinations, residence and housing practices within La Manzanilla vary along lines of class, mobility, and motivation. There are more seasonal than full-time lifestyle migrants in La Manzanilla; full-time residents are more likely to own a home, while seasonal residents are equally likely to own or rent; seasonal residents are more likely to be upper class, while full time residents are more likely to be middle class. This pattern makes sense when the cost of travel, multi-sited residence, and employment are taken into consideration. To live in La Manzanilla seasonally means that you most likely maintain a residence elsewhere, you can afford the transportation costs associated with seasonal residence, and you do not have to consider employment (which could be because of independent wealth, retirement, or the ability to work remotely). Among full time residents I knew in La Manzanilla, many maintained only their Mexican residence, and many worked or owned businesses in town. Retired full-time residents were more likely to own a home, while younger working residents and older residents living off a US Veterans Administration pension were more likely to rent. 
Despite their heterogeneity, lifestyle migrants in La Manzanilla demonstrate a high level of community involvement when compared with the elite enclave lifestyle migrants in the region. One lifestyle migrant interpretation of the difference between lifestyle migrants and tourists is that "the people that are building here are becoming part of the community", whereas tourists are, "just coming and going" (Interview 2/28/13). This engagement with community connects with an idea of "home" that extends beyond four walls, beyond a natural landscape, to the people who inhabit a place. This expanded concept of home is not necessarily limited to one location. Lifestyle mobility may establish multiple homes and senses of belonging (Cohen et al. 2015: 158). While community engagement does not erase hierarchies associated with class and nationality, privilege, and sometimes neocolonial perspectives, it does create more inclusive conditions for local agendas and control in community development than in exclusive luxury destinations where local residents are entirely absent, removed, or discursively reduced to scenery.

While lifestyle migration has been found to contribute negatively to sustainability in places that become overly saturated (Bastos 2014; Hayes 2015a, 2015b, 2015c; McWaters 2009) the impact of lifestyle migrants in La Manzanilla has materialized in a different fashion. Aspects of gentrification like a rising cost of living are impacting residents, although this process is proceeding at a much slower, smaller scale than in cities marketed as destinations, and development is still largely locally-directed. At this point, educational and employment opportunities are keeping pace with middle-class aspirations and the tourist/migrant market.

Increasingly, political ecology looks at the ways power operates within communities as well as upon them (Svarstad, Benjaminsen and Overå 2018). In human-human-environment relations power is "understood as a relational and productive force that generates contradictory effects within the same action" depending on position/perspective (Ahlborg and Nightingale 2018: 382). This attention to multiple relations of power addresses socioeconomic and spatial inequality and diversity of perspectives across scales (global-local) as well as within a given locality (Paulson 2015). I apply Bourdieu's (1986) discussion of the forms of capital to illuminate the reconfiguration of privilege and power in relationship between lifestyle migrant emplacement practices and youth entrepreneurialism. The successful acquisition of cultural capital over time is accomplished through emplacement practices involving education about how to be/have in a place, however, emplacement practices among lifestyle migrants in La Manzanilla are never one-sided. In other words, they are never about total immersion, but also involve concsiously and unconcsiously initiating changes in their adopted community. This transformative aspect of emplacement then changes the place and therefore the process of aquiring cultural capital. The process inevitably results in their participation in frameworks of knowledge production which set the terms of what is considered cultural capital.

Resident youth are positioned at a potential advantage in terms of locally recognized cultural capital. Initial accumulation of this capital begins at birth for those born into families with strong cultural capital. Youth who come from families which successfully navigate the confluence of local/lifestyle migrant influence potentially have the strongest cultural capital. This cultural capital translates easily into social capital, which in the case of La Manzanilla may extend beyond local spheres to include a transnational social network. It is through this cultural capital that resident youth are reconfiguring lifestyle migrant economic capital. Members of this generation appropriate this changed cultural capital through learning the language, environmental ideologies, behaviors, and consumption habits of lifestyle migrants. It is in some sense the flip side of the process in which lifestyle migrants learn to acquire their situated (local) cultural capital (Figure 2). Resident youth reconfigure this transmitted "double helix" cultural capital. Transforming lifestyle migrant economic and cultural capital into their own cultural, social, and economic capital, this generation is reconfiguring lifestyle migrant privilege and claiming the power to determine what kind of place La Manzanilla is, and what roles they will play there.

\section{Tierralegre: nonprofits and environmental education}

I found that proponents of locally-directed sustainable development in La Manzanilla were largely entrepreneurs (primarily youth in their twenties), and those who want the town to remain their hidden paradise were largely lifestyle migrants. This somewhat clumsy divide, however, is complicated in the work of local nonprofits. There are several locally-based organizations, including an educational foundation that offers 
scholarships and English classes; an annual spay and neuter clinic for animals; a community gym and wellness center; and a nonprofit bookstore that donates proceeds to local causes. Here I focus on environmental nonprofit Tierralegre, which has initiated several community projects including the Y.E.S. (Youth, Ecology, and Sustainability) initiative and Agro-Ecology Center. The Tierralegre Agro-Ecology Center has grown on 2,500 square meters donated by the ejido. I saw the space transform from an unused lot to a thriving garden and educational space between fall 2012 and summer 2013, and now in addition to garden beds, it includes an irrigation system, a worm composting system, a shade greenhouse, composting toilets, and a kitchen with a grey-water bio-filter system. The center is primarily constructed out of bamboo and recycled materials. Tierralegre has now expanded the initiative to other schools in the La Huerta municipality.

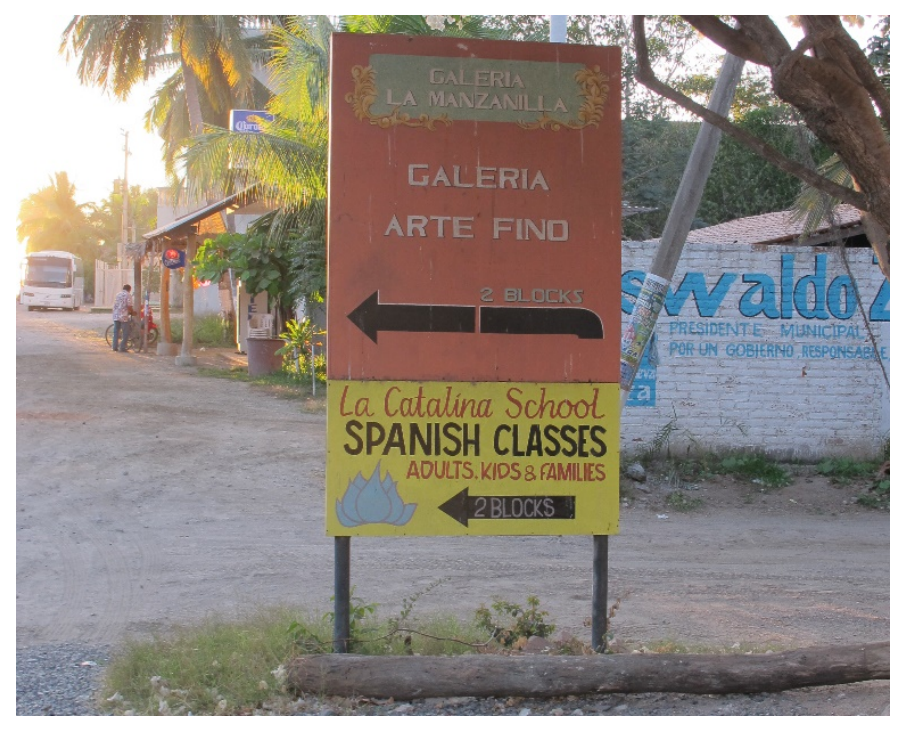

Figure 2: Signboards in La Manzanilla. Source: Author.

Nonprofit projects like the educational garden and ecology center assemble lifestyle migrant and local Mexican residents around community development initiatives focused on particular visions of sustainability. These projects primarily target the current generation of school-aged La Manzanilla youth, and their success is largely dependent on the positive response and participation of this generation. Through participation in this environmental education, youth in La Manzanilla, like Tsing's Indonesian nature lovers' clubs (2005), are indoctrinated into international, cosmopolitan ways of appreciating nature. This appreciation extends to agriculture, as new meanings and methods are attached old practices.

With the Y.E.S. initiative, Tierralegre highlights a vision of sustainability that involves the interdependence of environmental, sociocultural, and economic sustainability. The Y.E.S. project integrated educational gardens as part of the secondary school curriculum in La Manzanilla. I observed this educational garden project highlight the connection between environmental and economic sustainability by having students both consume the produce they grew in the garden, and also sell it at the weekly market and to local restaurants. At the end of the rainy season (and beginning of optimal planting season) in October 2012 I accompanied lifestyle migrant and founder of Tierralegre to the ejido-donated lot which would become the educational garden and Agro-Ecology Center. He stressed that the goals of the project were focused on youth education about permaculture and to instill a sense of the economic value in producing your own food. A few weeks later at the first day of class at the newly cleared garden site he described the goals of the project to approximately 30 secondary school students as they discussed the meanings and importance of orgánico and agricultura biointesivo. 
Locally grown organic produce had an additional consumer value to the lifestyle migrant patrons of the weekly market where students sold what they grew at the garden. The value of local organic produce and the types of produce being grown and sold, including greens such as kale and arugula, were appealing to lifestyle migrant consumers because it reflected their tastes in current food and health trends, and was not typically available at the small stores in town. It appealed to the sensibilities of lifestyle migrants familiar with the "buy local" movement in the U.S., and it kept them from seeking out these specialty goods in the Manzanillo bulk food chain, Sam's Club (1 hour south of town). The focus on interrelated environmental, social, and economic sustainability are stated clearly on the organization's website: "We are going directly to the root of our environmental problems, which are intrinsically social, by placing the necessary tools in the hands of youth, the future leaders of, and participants in, society" (www.tierralegre.org). The website describes environmental education as central to their vision of sustainable development.

How do localized discourses and practices reveal understandings about what needs to be maintained and what needs to be developed to sustain various imaginaries of this place? There is a dynamic relationship between youth entrepreneurialism and lifestyle migrant emplacement practices which is creating the conditions for a locally-directed sustainable development. La Manzanilla youth are taking environmental education and pairing it with learned cultural understandings about what is desirable in terms of lifestyle and consumption practices and based on these transmitted imaginaries, are developing businesses designed to attract more lifestyle migrants and tourists interested in the environmental amenities popular in ecotourism imaginaries. The idea that lifestyle migrant presence in the community means money and a potentially viable source of income as local youth imagine, talk about, and shape their futures, is a significant factor in entrepreneurial initiatives. But there is also a desire for what they have described as a cosmopolitan influence that (perhaps for generational and experiential reasons) is not widely shared by the elder generation. Part of this influence is reflected in the popular youth sentiment that they want to maintain a place that attracts foreign residents, including preservation of the environment that provides a landscape of natural amenities. A local entrepreneur in her twenties who had collaborated in an environmental education initiative with Tierralegre at the time of my research stressed the value of self-determination and sustainability, reflecting, "I think it's up to us to decide what kind of town and what kind of development we want. If we want to go the sustainable way and keep it ecofriendly...or if we want to just sell out" (Interview 3/6/13).

\section{Local conservation and ecotourism}

Lifestyle migrants and local nonprofits are not the only factor in the circulation of environmental ideologies and ecotourism imaginaries that inform local conservation and entrepreneurial practices. In 2008 Estero La Manzanilla was officially designated a Ramsar site. Ramsar is an international environmental agreement which became active in the 1970s, focused on concern with wetland habitat loss. Sites are designated based on a criteria intended to identify areas of "international importance" including rare wetland types and biological diversity (www.ramsar.org). Mexico has 142 Ramsar sites totaling 8,643,579 hectares. The wetland site in La Manzanilla includes 264 hectares, and is described as:

An estuarine system located in Tenacatita Bay, one of the five most important bays of Mexico's Pacific coast, surrounded by large clusters of mangrove in good condition, including Rhizophora mangle, Laguncularia racemosa, and Conocarpus erectus. A variety of flora and fauna species are also found, e.g., the site is one of the three areas with large populations of the American crocodile (Cocodrylus acutus). The estuary is essential for the reproduction of several species of aquatic animals and holds the largest reproductive colony of Boat-billed Heron (Cochlearius cochlearius) in the area. 55 different species of aquatic birds have been identified, and 42 different species of fish, of 10 different orders and 21 families, use this area as feeding ground (Ramsar Sites Information Service 2016).

Ramsar also identifies threats to this site of environmental significance, citing human impacts of urban growth and deforestation since 1970, and pointing to the construction of a coastal road in particular. This paved road 
has negatively impacted the mangroves and estuary by restricting natural water flows and increasing human traffic.

For environmental conservationists, such as those associated with Ramsar, biodiversity is a valued resource worthy of protective efforts. Institutions like Ramsar circulate environmental ideologies and imaginaries of sustainability that highlight the preservation and protection of environments they consider valuable. Valuable environments, such as the mangrove lagoon in La Manzanilla, are determined to be negatively impacted by infrastructure development such as a nearby paved highway connecting La Manzanilla and small neighboring towns with destinations and ports like Puerto Vallarta (to the north) and Manzanillo (to the south). That highway provides access to flows of tourists coming from airports in these larger cities.

Local residents Carlos and Miguel advocate conservation and ecotourism as a healthier means of economic development not just for La Manzanilla, but around the world (Interview 9/23/13). At the time of our interview, their ecotourism business was comprised of five ejidatarios (members of the ejido) and five family members of ejidatarios. As Carlos explained it, I understood the relationship between the ejido and ecotourism development in La Manzanilla had not always been optimally productive. There had been fluctuating support for ecotourism development that increased and decreased with the coincidence of government support. Still, members of the ejido were influential and significant figures when it came to development decisions in the community, and integral to ecotourism development. Outside entities, such as Ramsar, as well as lifestyle migrants and locally-based environmental and educational nonprofits have also played a significant role in imagining and materializing sustainable development in La Manzanilla. Miguel and his uncle identify ecotourism activities like whale watching, snorkeling, stand-up paddle boarding, hiking, swimming, birding, and boating with three primary sites; the ocean, the mangrove lagoon, and the jungle waterfall. Miguel believes that development is inevitable, and adds, "in the end, for me the idea behind any development is that you have to achieve it in the most sustainable way" (Interview 7/15/2013).

Ecotourism has been suggested by biologists and conservationists working in the tropical dry forests that dominate the coastal landscape in their plan for sustainable development. These researchers suggest a shared vision and implementation of sustainable development in the area is possible only with collaboration among local residents, ejidatarios, and officials in the municipal, state, and national government (Maass et al. 2005). Focusing on the Chamela region (in the same municipality as La Manzanilla) they propose three possible scenarios for the region's future. The first scenario posits increased deforestation for agricultural and ranching activities, which are not ideally suited to the environment in terms of land and weather patterns, and would not increase economic benefits while drastically decreasing ecological benefits. The second scenario ventures a future of massive tourism development following the model of Puerto Vallarta. They propose that while this scenario might increase economic opportunities to the area, these opportunities would not likely go to current residents but rather service workers migrating in from other areas. The fresh water consumption necessitated by this scenario would also be unsustainable. The third scenario proposes sustainable management of the area. The implementation of this Ecological Land Use Plan in cooperation with local residents, government officials, and scientists would involve sustainable agricultural and ranching activities in combination with "the development of a low-impact tourist industry", and suggest, "activities of ejidatarios, currently centered in agriculture and cattle ranching, may expand to a wide range of alternatives including forestry management and ecotourism" (Maass et al. 2005: 15).

\section{Ecotourism and sustainability from the bottom-up or top-down: discordant meanings and manifestations}

As exemplified in the diverse cases on the Costalegre, the label "ecotourism" has been used to describe low environmental impacts and increased economic opportunities in protected landscapes. It has been hailed as a tool of sustainable development. In practice, the ecotourism label has been applied in projects that resonate with local interests, but it has also been used to describe tourism development implemented from transnational corporations with little attention to local needs, or even environmental sustainability (Honey 2006).

Like ecotourism, labels including the prefix "sustainable" are widely applied. "Sustainability" is often defined as interconnected environmental, sociocultural, and economic practices that support the present 
generation without compromising future generations. This definition is rooted in a 1987 report by the World Commission on Environment and Development and has been critiqued as vague and consequently opening the door to the misuse of the word "sustainable" by corporate interests (Carrigan 2011: 6; Fricker 1998: 191). Models of sustainable development generally fall into two contrasting camps: top-down, or bottom-up. Topdown typically describes a neoliberal capitalist model of sustainability imposed from the outside. A common example is ecotourism focused on a convergence of environmental sustainability and economic sustainable development (Alexander 2018; Hill, Byrne and Pegas 2016). Even with an appreciation for environmental preservation, sustainable development as exemplified by corporate ecotourism models is still development based in "a top-down, ethnocentric, and technocratic approach, which treated people and cultures as abstract concepts" (Escobar 1995: 44). In contrast, models of bottom-up, grassroots sustainability initiatives are based in local environmental and social movements (Bastos 2014; Escobar 1998, 2008).

So far I've described sustainable community development practices and aspirations more representative of a bottom-up, grassroots model. Now I shift to a discussion of the other model present on the southern Jalisco coast - top-down. The lifestyle migrant history of this end of the coast begins with a European billionaire's dream home, and is populated with a class of lifestyle migrant with wealth far exceeding those in La Manzanilla. The class distinction is so extreme, it raises a question about grouping these diverse foreign residents into the same category of "lifestyle migrant." I suggest that while they may share some motivations for building homes on this Mexican coast, their divergent understandings of home and community have led to very different visions and materializations of what is described in both settings as "sustainable" development, prompting the question; sustainability for whom?

\section{Elite eco-utopias: the "discovery" and construction of paradise by a different class of lifestyle migrant on the Costalegre}

There were no mail-order catalogues in 1492. Marco Polo's journal was the wish book of Renaissance Europe. Then, Columbus sailed the ocean blue and landed in Sears' basement. Despite all the Indians on the escalator, Columbus' visit came to be known as a 'discovery.' (Robbins 1971: 227)

The powerful ecotourism imaginary of the discovery of exotic remote natural landscape paired with comfortable amenities is reproduced in current development projects on the Costalegre. In 2013 the LA Times reported that this area was on the verge of major changes, both from transnational migrations and internal policy changes happening from within the Mexican government. This stretch of coast is "bracing for more than \$1 billion in new resort projects, including residential subdivisions and condo towers" (Fausset 2013). Costalegre stretches between Puerto Vallarta, Jalisco, and Manzanillo, Colima. It is described by travel writers alternately as "blissfully underdeveloped" but also with words like "luxury" and "decadence" (Chaplin 2016). A March 2015 article, "Costalegre's New Airport Set to Boost Jet Set Destination", reported that within the next several years the completion of a new airport will boost tourism to the area, and claimed the "distinct crowd" the Costalegre attracts is drawn to the natural landscape, amenities, and the "exotic, bohemian, remote, off the beaten path" character of the area (Figueroa 2015: 2). The article ensured that despite the increase in visitors, "the master plan for the Costalegre area calls for low density eco-oriented tourism...it won't change the feel of Costalegre. Nor will other new developments in the pipeline" (Figueroa 2015: 4). In 2017 the international airport remained in limbo, with an airstrip in existence for years, but still lacking funding to complete the terminal (Drillinger 2017). The anticipated completion date was the end of 2018. In late 2020, there were reports of an airport opening within 18 months. ${ }^{2}$

This stretch of coast just north of La Manzanilla has a unique history that sets the stage for the exclusive luxury resort development for which it is now known. Careyes was established as a luxury destination by Gian

\footnotetext{
${ }^{2}$ https://theguadalajarareporter.net/index.php/news/news/pacific-coast/46277-new-costalegre-airport-will-detonate-
} tourism-in-region-state-officials-hope 
Franco Brignone, an Italian oil mogul and artist who built his mansion-sized vacation home in 1973 when the Manzanillo international airport opened, and later in 1976 built the luxury El Careyes beach resort. He started selling land to other mostly European elites for their own vacation homes in an area that offered a secluded pristine paradisiacal setting. Careyes continues to cater to the international jet set with Brignone's son, Giorgio, now running the Careyes real estate operation and polo club (Vaucher 2005, Figure 3).

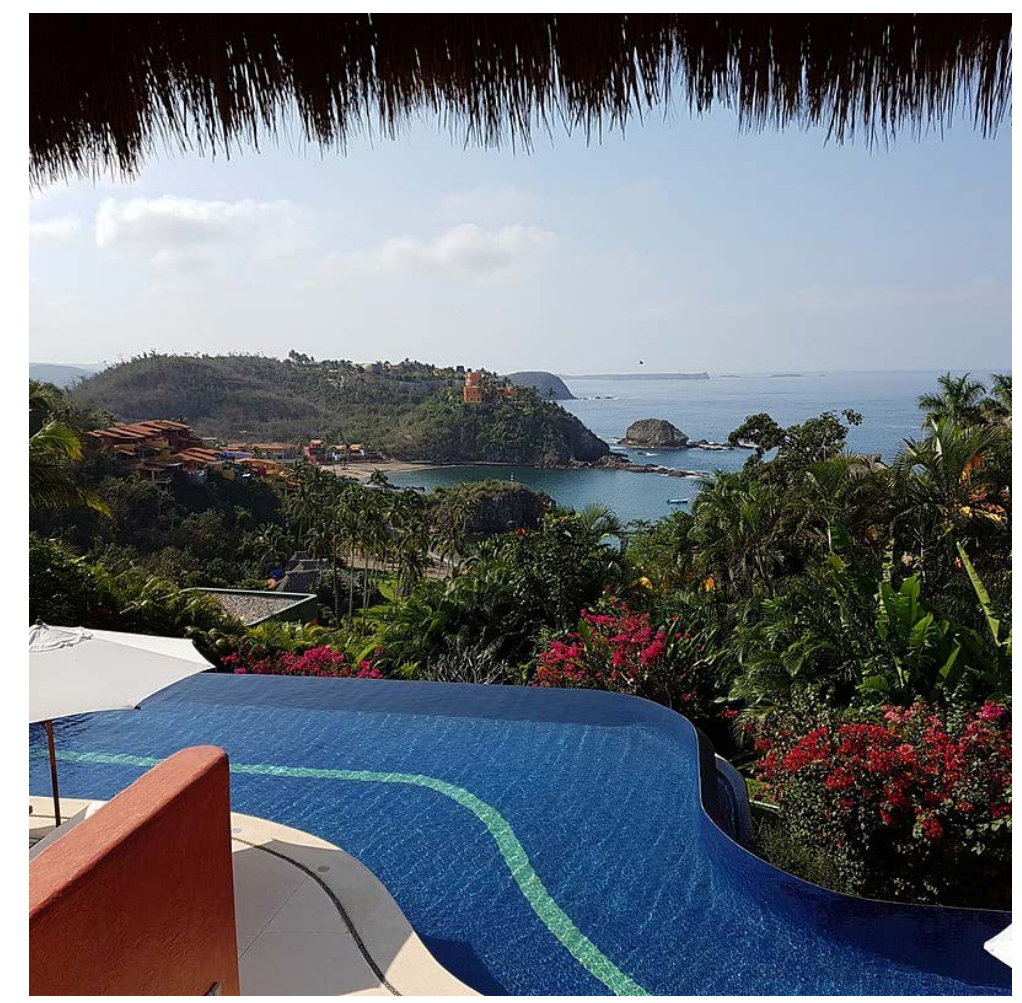

Figure 3: Casa de Careyes. Source: Wikimedia Commons.

Travel writer Perrottet describes Careyes as a utopian community (2014). He traces the history of its development into an elite oasis, from what he describes as wild coastline to "one of the world's most eccentric and glamorous refuges. Luxury outposts in remote locations are now a staple of five-star travel, but Careyes was a pioneer in the field, conceived on a scale impossible to imagine today" (Perrottet 2014: 2). He relays the Brignone family's nostalgia for a time they could take advantage of local fishermen with their cosmopolitan capital:

The Brignone family fondly remembers the days when pages of Playboy magazine served as currency. Back in the 1970s, local fishermen would row from their trawlers to the beach with a crate full of live shrimp and proceed to barter for erotica with the Italian family, who were then living in rustic isolation by the sands. 'Three pages of Playboy was the going rate for an entire crate,' explains Filippo Brignone, now in his early fifties. 'And a few coconuts.' (Perrottet 2014: 2).

This fond recollection reads as unabashed colonial exploitation - buying fish with Playboy like buying land with beads - the idea that the cosmopolitan goods they had were worth more than money and even though they could certainly afford to purchase fish in a way that would contribute to the local economy, they did not. 
Nearby, Chamela is the site of Brignone's friend Sir James Goldsmith's "dream home" in what was described in his biography as "a virgin jungle on the west coast of Mexico" (Fallon 1991: 439). Goldsmith's biographer describes the decadent creation of the dream home:

It would not, however, be just another home - he had three already - but his dream home, the first which would entirely reflect his own interests and personality, which would be built from scratch and which would have all the room his restless nature craved. Unlike the great English and French barons who built their houses in other countries, Goldsmith, as the most international (the most fashionable word is 'global') of international businessmen, could choose anywhere in the world within reasonable range of his private jet. He chose Mexico because of the climate, the wildness, and the extraordinary beauty of the land on the coast. (Fallon 1991: 439)

This quote was meant to suggest more about Goldsmith than the stretch of coast where he erected his dream home. This home of Goldsmith's would be unlike his other three - it would be his own personal paradise, an unconstrained expanse to support his "restless nature." This passage describes Goldsmith as the exemplar cosmopolitan subject, distinguishing him as having the taste and resources to select this distant coastal Mexican locale. What was left unsaid but suggested is that it was in part this location's distance from Goldsmith's European homes that added to its potency as a paradise. That he was limited only by the "range of his private jet" says that he was not, in fact, limited by distance at all. The farther away this paradise existed from his other homes, the more it added to his status. Beyond status among other elites, it entrenches Goldsmith in a narrative of colonial visionaries - seemingly unchecked by economic, political, or social restrictions - able not only to select a private paradise from anywhere in the world, but possessing the discriminating taste and bold sense of adventure to select this unheard of location described as "wild" and "virgin." Virgin jungle denotes an untouched landscape, and hinted at the moment the natural landscape will succumb to be molded into Goldsmith's ideal image. The value of the place as landscape here was in large part its "natural" blank canvas - its seeming availability to be turned into this rich man's fantasy home - his personal paradise.

A biography of the architect, Robert Couturier: designing paradises (2014), describes the creation of the estate, highlighting the magnitude of the dream house. The architect:

Landed a job of unimaginable proportions - the complete design of Cuixmala, financier Sir James Goldsmith's twenty-thousand-acre Mexican vacation estate, from the monumental architecture to the smallest of decorative details. Goldsmith had already hired one team of architects and builders in Mexico, but was disappointed by their proposals. 'Jimmy had told them he wanted palaces,' says Couturier: 'But for a normal person, a palace is difficult to translate into reality it's a fairy tale.' (Couturier and McKeough 2014: 120)

Couturier described the process that spanned two years and took a thousand laborers.

'It was like building a whole town.' The job included guest houses scattered across the area's hilltops; a village for workers; and two notable palatial homes - La Loma, Goldsmith's sixtythousand-square-foot mountaintop residence.... and a separate seaside residence for his ex-wife. (Couturier and McKeough 2014: 120)

Elaborate transformations of the landscape were imposed in Careyes on a similar scale. The transformation of the landscape preceded the elite cosmopolitan community. One notable feature was the polo field. In "Mexico's hedonistic haven" a travel writer describes the "impressive horticultural miracle of Bermuda-grass polo fields in the heart of the Jalisco jungle" as a draw for "elite athletes and their beautiful followers to tournaments sponsored by Cartier and Moët and Chandon" (Penaloza 2010: 3). This literal rewriting of the landscape to suit the fantasy culminated in the establishment of a utopian community (transient though it may be) of global elites. 
Elite cosmopolitanism is celebrated here - "caftan-clad doyennes slip between French, Spanish and Italian, often in the same sentence. Legendary house parties attract guests like Giorgio Armani, Francis Ford Coppola, Cindy Crawford and Bill Gates" (Penaloza 2010: 3). Brignone and Goldsmith's personal narratives and contemporary travel writing congealed the idea of these places collectively as a utopian community of elites. Giorgio Brignone describes this vision alternately as lifestyle and community:

Careyes is not for everyone...Yes, this is geared to the luxury market, but with an edge. We developed this international haven to embrace, not conquer, the jungle. Living the Careyes lifestyle requires an improvisational spirit - and an adventurous heart. (Penaloza 2010: 3)

This description of community is not of local Mexican inhabitants, but of elite vacationers: "There are not many places that offer polo and the chance to spend time on the beach with the family. And here, the community invites players into their homes and has parties and dinners for them - you become a part of the place." (Middleton 2010: 5). Clientele that compose this fluid elite community are described as European aristocrats, British billionaires, South American playboys, and Hollywood celebrities (Perrottet 2014; Penaloza 2010). The Careyes resort serves a vital function for the jet set, as:

An antidote to the overkill of St. Tropez, there are no magnums of Moët at the marina, no tongues wagging with yacht envy and zero glitzy nightclubs. Conspicuous consumption is considered mortifyingly déclassé: European royalty and Hollywood starlets hit the beach wearing whatever they woke up in, basking in the sunshine of leaving the paparazzi far, far behind. (Penaloza 2010:

2)

This description elicits the familiar story of tourism as a necessary rejuvenating escape, but the object of escape is familiar only to a class of tourists accustomed to partaking in magnums of champagne and dodging the paparazzi. This destination is elevated as one in which the elite tourist will not have to labor at displaying wealth and status - it is a privileged escape from the burdens of privilege.

\section{Exclusive ecotourism}

The wealth that claimed these elite spaces and transformed them into private paradises is also being invested in ecological conservation. Since the 1970s the Careyes Foundation has released more than 200,000 turtles as part of its Sea Turtle Protection Program (Penaloza 2010). In 2013 the Careyes Foundation reportedly began to focus on providing environmental, arts, and educational programs for the local community (although it is unclear which local community the foundation is benefitting) (Perrottet 2014). Environmental preservation concerns align closely with aesthetic and privacy concerns for the elite families and guests of Careyes and Chamela. Giorgio Brignone complains that "the problem with many places in Mexico is that a beautiful place has something horrible just on the other side", and explains that the protected area around Careyes alleviates any unsavory views, noting, "We're also surrounded by an enormous nature reserve, which helps give it a magic that doesn't exist anywhere else" (Middleton 2010: 5).

Sir James Goldsmith died in 1997, and donated much of the land that comprises the Chamela-Cuixmala Biosphere Reserve (Figure 1). His heirs are some of the harshest critics of currently proposed luxury tourism development neighboring the reserve. While a concern for the preservation of the natural environment undoubtedly influenced the decision to donate land to create the reserve, it is also notable that the Goldsmith dream estate still stands, now protected from infringing development and open to guests. The ChamelaCuixmala Biosphere Reserve is a tropical dry forest reserve that protects 13,142 hectares of forests and marshes in the La Huerta municipality, where La Manzanilla is also located (Sánchez-Azofeifa et al. 2009). The privately owned reserve includes a UNAM biological research station, established in 1971. In 1988 the Ecological Foundation of Cuixmala was established, and in 2006 the reserve was designated an UNESCO Biosphere Reserve. Environmental scholars have determined that efforts at the reserve have effectively protected the area 
thus far, but have been less successful at promoting regional conservation and sustainable development (Sánchez-Azofeifa et al. 2009). They suggest residents of the surrounding ejidos be trained in alternative ecosystem management strategies to conserve resources, rather than using land for agriculture or pasture, or selling properties for tourism development. Twenty-seven ejidos border the reserve, comprising $70 \%$ of the proximate area, and the remaining land is divided between tourist developments and private properties. The cooperative project of alternative ecosystem management would be called Red de Areas Ejidales Protegidas (Ejidos' protected area network) (Sánchez-Azofeifa et al. 2009).

Back on the estate, Travel and Leisure writer Austin "steps inside the fantasy" in 2016 and visited Goldsmith's daughter, Alix Goldsmith Marcaccini, who assured Austin that, "Daddy would not have wanted Cuixmala to become one of those dead places, where rich people go only to drink cocktails" (2016: 1). She explains, "Daddy loved the idea of having his family around him in the jungle, where we could be surrounded by beauty", and how "it took forever to buy the land from different owners-and then two years and two thousand workers to build all the houses" (Austin 2016: 1). Not all the land was successfully acquired, however, and the author described the juxtaposition of real and fantasy life;

On the grounds of Cuixmala, within sight of the casitas' swimming pool, is an almost too real village surrounded by luxury. An abandoned car engine and collapsed tin-roof shack are juxtaposed with flowers in plastic buckets, Mickey Mouse towels, and the inevitable satellite dish. Inside a tiny convenience store, workers are chomping on Doritos, falling silent in the presence of a stray gringo. The owner of the village refused to sell the land to Goldsmith, although the residents now have free access to Cuixmala-monitored water and security. (Austin 2016: 4)

Locals are mentioned only as an odd foil to the fantasy Goldsmith constructed, or described in the context of friendly service providers, such as Austin's mention of "the resolutely helpful maids...given to spreading flowers and good cheer throughout every room" (2016: 5). As a travel writer, Austin describes the appeal of this combination of natural beauty, decadence, and glimpses of real life as "what makes it interesting and authentic" (2016: 4). He describes the coast as a series of neighboring resorts, leaving out the towns, like La Manzanilla, in between:

On the opposite side of Cuixmala is another Starwood property, El Tamarindo. As neighbors, the three resorts have an uneasy symbiotic connection: some Cuixmala guests play golf at Tamarindo, and the Goldsmith brigade stayed at Careyes before Cuixmala was built. One international sort describes the scene then as 'a leftover sixties set, going from pleasure to pleasure'. (Austin 2016: 5)

Goldsmith's daughter, who the author describes as "a devout environmentalist who loves Mexico", has transformed the estate ${ }^{3}$ into "a combination working farm, relentlessly hip eco-resort, colossal bed-andbreakfast, and politically correct watering hole for the neo-glitterati", including guests like Madonna, Mick Jaggar, and Quentin Tarantino. This is a slightly different crowd of celebrities than the likes of Ronald Reagan and Richard Nixon, who visited the estate when her father was alive (Austin 2016: 2). The idea of environmental consciousness and preserving the natural beauty of the area along with the privacy sought by elites and celebrities, dovetails with the tourism trope of the inevitability of more tourists discovering and ruining the destination.

In contrast, over the last forty years, "Gian Franco has maintained an iron grip on Careyes, limiting growth to one beachside hotel with 48 rooms, 36 casitas on a hill above a cove, and some 50 villas with sweeping views out over the bay" (Middleton 2010: 3). One travel writer describes the "little patch of paradise" connecting the Careyes and Chamela properties as "a playground for heiresses, dignitaries, and royalty", and

${ }^{3}$ https://cuixmala.com/ 
most recently, "Hollywood and its orbit have descended on this remote land, along with ordinary millionaires looking for a little pedigree and a way into an often sealed-off world" (Middleton 2010: 3-4). They raise concern at further discovery, questioning: "As the glare of the spotlight inches closer, how do you protect this sequestered world of private villas and hidden bungalows, this luxe and aesthetically consistent Mexico that is almost impossible to find elsewhere?" (Middleton 2010: 4). These sites demonstrate a concern with protecting the environment because it sets the scene for this elite tourist escape.

Two planned luxury tourism development projects in the area, Tambora and Careyitos, are described by developers as luxury "eco-resorts." Developers claim they will engage in conservation practices that will offset negative environmental impacts, but despite these environment-friendly claims, the development projects have met with protest by those who consider this "eco-development" a threat to the reserve. Protesters include the Goldsmith family and the scholars and researchers that comprise the Association for Tropical Biology and Conservation. More than 700 members of the Association for Tropical Biology and Conservation appealed to the Mexican government to halt tourism development in the area. The Association released the Morelia Declaration in July 2007 advocating for the protection of the tropical dry forests in Jalisco (Barclay 2007). Environmental group Greenvest.org is advocating a coalition of government authorities, academic institutions and civil organizations to battle this tourism development.

Although geographically very near to these sites of decadent escape, La Manzanilla's discursive and material production as a tourism and lifestyle migrant destination contrasts significantly with the imaginaries of secluded luxury destinations on the Costalegre. A third case, geographically situated between La Manzanilla and Careyes/Chamela, is the story of a displacement of a local community by a wealthy developer's land claim and plans for sustainable development.

\section{Development and displacement: the case of Tenacatita}

Neighboring La Manzanilla to the north is Tenacatita, which was subjected to a hostile takeover by elite resort developers in 2010. Tenacatita is the name of both the bay and the beach town where many residents of the community of Rebalsito, immediately inland from Tenacatita, ran businesses, and where some also lived. On August 4, 2010 state auxiliary police carried out the eviction of Tenacatita residents and business owners under the orders of a Guadalajara developer who claims to be the legal owner of this strip of beach, and whose goal is to develop Tenacatita into a luxury tourism destination on the Costalegre.

During my fieldwork lifestyle migrant and Mexican residents of La Manzanilla referred me to an activist, a lifestyle migrant and now Mexican citizen who was organizing the community effort to retake their beach. She immediately responded to the takeover by organizing monetary donations to buy food and supplies for evicted residents and business owners, and later participated in the legal efforts to reclaim the land. She explained what took place in the early morning hours of August 4, 2010. At around 4 a.m. armed men arrived and went door to door evicting people, they "had guns and gave people five minutes to get their stuff and go" (Interview 7/11/13). She described the violence and destruction of property that occurred during the eviction, resulting in "everybody losing everything - their livelihood, their homes. And that was it. And then they put up these fences and gate." The beach was re-opened to the public in June 2013, but businesses and homeowners were not allowed to return and rebuild, "so it's like the beach is open", she explained, "but it's not really open."

The most recent update reports Tenacatita is uninhabited and hosting two separate sets of guards; one set to ensure the public has daily access to the beach, the other to ensure that the public stay within a strictly delineated area of the beach, and that no businesses return to the locations they previously occupied on the beach. While the governor intervened to open the beach to public use, residents and business owners are still prohibited from rebuilding and returning to the beach. The court case with Guadalajara businessman, José María Andrés Villalobos, continues. Villalobos claims that his corporation is "going to make this a place that the country deserves", and "elevate the name of Jalisco" by developing luxury tourism destinations using Careyes as a model (Guadalajara Reporter 8/27/10, La Jornada 6/21/11). He argued that the development would create jobs for locals and enhance quality of life with improvements such as a water treatment plant. Meanwhile, former Tenacatita business owners, including fishermen, divers, restaurant owners, tour guides, and shop owners, have found refuge in La Manzanilla. 


\section{Conclusion}

What does this coastal region tell us about "sustainable development"? The forms of sustainable development materializing in the town of La Manzanilla and the luxury enclaves to the north are in many ways as dramatically different as the class of lifestyle migrants that inhabit them. But there is some overlap in the environmental ideologies evident in the region. Both spaces include residents who are critical of unchecked growth and expansion. Both are motivated by leisure consumption practices and enabled by privilege. Both value the natural landscape and biodiversity. But they depart this shared sensibility around the issue of home and community. Unlike the luxury eco-enclaves, lifestyle migrants and local residents in La Manzanilla are largely invested in the place as a community they consider home beyond the four walls of their houses. Despite what might be understood as neocolonial positioning, this expanded sense of home includes valuing local residents as neighbors, not just part of the local scenery.

The relationships between residents and the environment in La Manzanilla articulate patterns of global mobility and consumption alongside local sustainable development initiatives. Many residents believe a future in which the community survives and thrives involves environmental sustainability that enhances economic and social sustainability. This means locally-directed development that reduces the negative impacts of tourism and lifestyle migration such as displacement and seasonal gaps in employment, and preserves the natural environment which draws tourists and enhances quality of life for residents. While this locally-directed development is not always unified, and includes conflicting interests among nonprofits, ecotourism businesses, local government, and residents, I suggest that the frictions created in the intersection of lifestyle migrant capital, environmental ideology, and ecotourism imaginaries has created conditions of viable community development. This productive friction might draw from similar environmental ideologies as proximate elite eco-enclave development, but manifests materially and in practice in ways that support social sustainability rather than erasing or evicting local communities.

Dominantly positioned environmental discourses are reproduced, but also reframed and challenged in local contexts. They are reworked in the framework of local autonomy and control over development, creating conditions that resist the type of hostile takeover that happened at Tenacatita. This self-determination in local sustainable development initiatives is a key factor in social sustainability, which distinguishes the model of sustainable development in La Manzanilla with those of Careyes and Chamela. Local initiatives may not be taking shape in the form of a direct social movement geared toward claiming territory, like the founding ejido members did in 1936, or fighting to protect their territory against eviction and outside development interests. Rather, they are working within the frame of neoliberal models of sustainable development to create conditions for a sustained livelihood in their communities. For local youth entrepreneurs this idea is relatively new - to stay and build their futures in their home community rather than relocate to a city like Guadalajara, Puerto Vallarta or to head north of the border for economic opportunities.

The relationship between lifestyle migrant capital, youth entrepreneurialism, environmental ideology, and ecotourism imaginaries in this place have created conditions which are producing a locally-directed future outside of large scale resort development or elite enclave ecotourism. Diverse residents have created a coalition around a shared investment in their home, even if not explicitly formed in a unified vision. This productive friction is maintaining local control, and proving resistant to forces of displacement and disenfranchisement. In the words of a local youth entrepreneur, "it's up to us to decide what kind of town and what kind of development we want."

\section{References}

Ahlborg, H. and A.J. Nightingale. 2018. Theorizing power in political ecology: the where of power in resource governance projects. Journal of Political Ecology 25: 381-401.

Alexander, W. 2018. Testing the water, challenging the narratives of sustainable development: student volunteer research promoting public health in rural Panama in the shadow of an "eco-playground." Journal of Political Ecology 25: 64-79.

Austin, T. 2016. The Rise of Cuixmala. Travel and Leisure. Retrieved March 272016. http://www.travelandleisure.com/articles/castle-in-the-sand 
Banerjee, S. 2017. Long environmentalism: after the listening session. In Monani, S. and J. Adamson (eds.). Ecocriticism and indigenous studies: conversations from Earth to Cosmos. London: Routledge. Pp. 6281.

Banks, S.P. 2004. Identity narratives by American and Canadian retirees in Mexico. Journal of Cross-Cultural Gerontology 19(4): 361-381.

Bantman-Masum, E. 2015. Lifestyle transmigration: understanding a hypermobile minority in Mérida, Mexico. Journal of Latin American Geography 14(1): 101-117.

Barclay, E. 2007. The Morelia Declaration: protection of threatened tropical dry forests in Jalisco, Mexico. National Geographic News. Retrieved April 12, 2020. https://tropicalbiology.org/wpcontent/uploads/2013/07/MORELIA_DECLARATION.pdf

Barrantes-Reynolds, M-P. 2011. The expansion of 'real estate tourism' in coastal areas: its behavior and implications. Recreation and Society in Africa, Asia and Latin America 2(1): 50-67.

Bastos, S. 2014. Territorial dispossession and indigenous rearticulation in the Chapala lakeshore. In Janoschka, M. and H. Haas (eds.). Contested spatialities, lifestyle migration, and residential tourism. London: Routledge.

Benson, M. and K. O'Reilly. 2009. Migration and the search for a better way of life: a critical exploration of lifestyle migration. The Sociological Review 57(4): 608-625.

Berger, D. and A.G. Wood (eds.). 2010. Holiday in Mexico: critical reflections on tourism and tourist encounters. Durham: Duke University Press.

Bloom, N.D. 2006. To be served and loved: the American sense of place in San Miguel de Allende. In Bloom, N.D. (ed.). Adventures into Mexico: American tourism beyond the border. Lanham: Rowman and Littlefield.

Borrero, J., M. Ortiz, V. Titov and C. Synolakis. 1997. Field survey of Mexican tsunami produces new data, unusual photos. Eos, Transactions, American Geophysical Union 78(8): 85-92.

Bourdieu, P. 1986. The forms of capital. In Richardson J. (ed.). Handbook of theory and research for the sociology of education. Westport: Greenwood.

Bullard, R. 1999. Environmental racism and the environmental justice movement. In Merchant C. (ed.). Ecology: key concepts in critical theory. New York: Humanity Books.

Carrigan, A. 2011. Postcolonial tourism: literature, culture, and environment. London: Routledge.

Chaplin, J. 2016. Mexico's new Costa Alegre hideaways. Travel and Leisure. Accessed May 11, 2016. http://www.travelandleisure.com/articles/mexicos-new-costa-alegre-hideaways

Clancy, M. 2001. Exporting paradise: tourism and development in Mexico. Amsterdam: Pergamon.

Clausen, H.B. 2008. Negotiating membership in a Mexican transnational community: a study of North American immigrants in a Mexican border town. Diálogos Latinamericanos 14: 1-18.

Cohen, S.A., T. Duncan and M. Thulemark. 2015. Lifestyle mobilities: the crossroads of travel, leisure and migration. Mobilities (10)1: 155-172.

Couturier, R., T. McKeough and T. Street-Porter. 2014. Robert Couturier: designing paradises. New York: Rizzoli.

Croucher, S. 2009. The other side of the fence: American migrants in Mexico. Austin: University of Texas Press.

Drillinger, M. 2017. Big changes coming to Costalegre - eventually. https://www.travelweekly.com/MexicoTravel/Insights/Big-changes-coming-to-Costalegre. Retrieved April 12, 2020.

Escobar, A. 1995. Encountering development: the making and unmaking of the third world. Princeton: Princeton University Press.

Escobar, A. 1998. Whose knowledge, whose nature? Biodiversity, conservation, and the political ecology of social movements. Journal of Political Ecology 5: 53-82.

Escobar, A. 2008. Territories of difference: place, movements, life, Redes. Durham: Duke University Press. 
Fallon, I. 1991. Billionaire: the life and times of Sir James Goldsmith. Boston: Little, Brown and Company.

Fausset, R. 2013. A line in the sand over opening Mexico's beaches to foreign ownership. Los Angeles Times, October 7.

Figueroa, A. 2015. Costalegre's new airport set to boost jet set destination. Travel Agent Central, March 31, 2015.

Fricker, A. 1998. Measuring up to sustainability. Futures 30(4): 367-375.

Harvey, D. 2005. A brief history of neoliberalism. Oxford: Oxford University Press.

Harvey, D. 2009. Cosmopolitanism and the geographies of freedom. New York: Columbia University Press.

Hayes, M. 2015a. Moving south: the economic motives and structural context of North America's emigrants in Cuenca, Ecuador. Mobilities 10(2): 267-284.

Hayes, M. 2015b. Introduction: the emerging lifestyle migration industry and geographies of transnationalism, mobility and displacement in Latin America. Journal of Latin American Geography 14(1): 7-18.

Hayes, M. 2015c. Into the universe of the hacienda: lifestyle migration, individualism and social dislocation in Vilacamba, Ecuador. Journal of Latin American Geography 14(1): 80-100.

Hayes, M. and J. Carlson. 2018. Good guests and obnoxious gringos: cosmopolitan ideals amongst North American migrants to Cuenca, Ecuador. American Journal of Cultural Sociology 6(1): 189-211.

Hill, W., J. Byrne and F. de Vasconcellos Pegas. 2016. The ecotourism-extraction nexus and its implications for the long-term sustainability of protected areas: what is being sustained and who decides? Journal of Political Ecology 23: 308-327.

Honey, M. 2006. Treading lightly? Ecotourism's impact on the environment. In N. Haenn and R.R. Wilk (eds.). The environment in anthropology: a reader in ecology, culture, and sustainable living. New York: New York University Press.

Jackiewicz, E.L. and O. Govdyak. 2015. Diversity of lifestyle: a view from Belize. Yearbook of the Association of Pacific Coast Geographers 77: 18-39.

Janoschka, M. 2009. The contested spaces of lifestyle mobilities: regime analysis as a tool to study political claims in Latin American retirement destinations. Die Erde 140(3): 1-20.

Klein, N. 2005. The rise of disaster capitalism. The Nation. April 14.

Krauze, E. 1997. Mexico biography of power: a history of modern Mexico, 1810-1996. New York: HarperCollins Publishers.

Low, S. 2003. Social sustainability: people, history, values. In J. Teutonico (ed.). Managing change: sustainable approaches to the conservation of the built environment. Los Angeles: Getty Conservation Institute.

Maass, J. M. and P. Balvanera. 2005. Ecosystem services of tropical dry forests: insights from long-term ecological and social research on the Pacific Coast of Mexico. Ecology and Society 10: 1.

McWatters, M.R. 2009. Residential tourism: (de) constructing paradise. Boston: Channel View Publications.

Middleton, W. 2010. The Mexican Riviera. Departures. March 30. http:/www.departures.com/letters/features/mexican-riviera Retrieved April 12, 2020.

Morales, O.L. 2010. The US citizen retirement migration to Los Cabos, Mexico: profile and social effects. Recreation and Society in Africa, Asia and Latin America 1(1): 75-92.

Nadasdy, P. 2007. Adaptive co-management and the gospel of resilience. In D. Armitage, F. Berkes and N. Doubleday (eds.). Adaptive co-management: collaboration, learning, and multi-level governance. Vancouver: UBC Press.

Oliver-Smith, A. 2010. Defying displacement: grassroots resistance and the critique of development. Austin: University of Texas Press.

Paulson, S. 2015. Political ecology. In D'Alisa G., F. Demaria and G. Kallis (eds.). Degrowth: a vocabulary for a new era. London: Routledge.

Paulson, S. 2017. Degrowth: culture, power and change. Journal of Political Ecology 24: 425-448. 
Peet, R., P. Robbins and M.J. Watts. 2011. Global nature. In Peet R., P. Robbins and M.J. Watts (eds.). Global political ecology. London: Routledge.

Penaloza, S. 2010. Mexico's hedonistic haven. The Globe and Mail, October 1. http://www.theglobeandmail.com/life/travel/activities-and-interests/mexicos-hedonistichaven/article571292/ Accessed March 27, 2016.

Perrottet, T. 2014. Costa Careyes's utopian view. The Wall Street Journal. January 23. http://www.wsj.com/articles/SB10001424052702303933104579306602420176352 Retrieved April 12, 2020.

Peterson, N.D. 2015. Unequal sustainabilities. Economic Anthropology 2: 264-277.

Preston, J. and S. Dillon. 2004. Opening Mexico: the making of a democracy. New York: Farrar, Straus and Giroux.

Ramsar Sites Information Service. 2016. Estero La Manzanilla. https://rsis.ramsar.org/ris/1789, and "About" https://rsis.ramsar.org/about.

Riensche, M., A. Castillo, E. García-Frapolli, P. Moreno-Casasola and C. Tello-Díaz .2019. Private over public interests in regional tourism governance: a case study in Costalegre, Mexico. Sustainability 11(6): 1760.

Robbins, T. 1971. Another roadside attraction. New York: Bantam Books.

Sánchez-Azofeifa, G.A., M. Quesada, P. Cuevas-Reyes, A. Castillo and G. Sánchez-Montoya. 2009. Land cover and conservation in the area of influence of the Chamela-Cuixmala Biosphere Reserve, Mexico. Forest and Ecology Management 258: 907-912.

Spalding, A. 2013. Environmental outcomes of lifestyle migration: land cover change and land use transitions in the Bocas del Toro Archipelago in Panama. Journal of Latin American Geography 12(3): 179-202.

Stonich, S. 2008. International tourism and disaster capitalism: the case of Hurricane Mitch in Honduras. In Gunewardena, N. and M. Schuller (eds.). Neoliberal strategies in disaster reconstruction. Lanham: Altamira. Pp. 47-68.

Svarstad, H., T.A. Benjaminsen and R. Overå. 2018. Power theories in political ecology. Journal of Political Ecology 25: 350-363.

Truly, D. 2006. The Lake Chapala Riviera: the evolution of a not so American foreign community. In N.D. Bloom (ed.). Adventures into Mexico: American tourism beyond the border. Lanham: Rowman and Littlefield.

Tsing, A. 2005. Friction: an ethnography of global connection. Princeton: Princeton University Press.

Tsing, A. 2012. Frictions. In Ritzer, G. (ed.). The Wiley-Blackwell encyclopedia of globalization Vol.2. Oxford: Wiley-Blackwell. Pp. 707-709.

Van Noorloos, F. 2011. A transnational networked space: tracing residential tourism and its multi-local implications in Costa Rica. International Development and Planning Review 33(4): 430-444.

Vaucher, A. 2005. A Mexican trendsetter. New York Times, March 11. 